INTERNATIONAL JOURN AL OF RESEARCHES IN BIOSCIENCES, AGRICULTURE AND TECHNOLOGY (c) VISHWASHANTI MULTIPURPOSE SOCIETY (Global Peace Multipurpose Socie ty) R. No. MH-659/13 (N) www.vmsindia.org

\title{
EFFECT OF CROP WASTES/BYPRODUCTS ON NUTRITIONAL AND MICROBIAL COMPOSITION OF VERMICOMPOST USING EARTHWORM EUDRILUS EUGENAE.
}

\author{
R. S. Tambe \\ Dept. of Zoology, Arts, Commerce and Science College, Satral, Tal: Rahuri, Dist: Ahmednagar (MS), India. \\ ramstambe@gmail.com
}

\begin{abstract}
:
Effect of crop for the growth and multiplication of plants, microbes and various other Organic matter is an important constituent of soil, which include, un decomposed and partially decomposed plant and animal residues, the live and dead micro organis ms, as well as highly decomposed and colloidal end product called humus. In the biological system, plants as producers, animal and man as consumers and soil organisms as decomposers are dependent on each other in a particular habitat called eco system. Earthworms bio convert the organic wastes into plant nutrient resources and the reby act as catalysts in protecting our environment.
\end{abstract}

Keyw ords: Microbial composition, Vermicompost, earthworms, waste.

\section{Introduction}

Vermicomposting has been reported to be a viable, cost-effective, and rapid technique for the efficient utilization of crop residues and byproducts and organic wastes. It provides two use ful products; the earthworm biomass and the Vermicompost. Earthworms eat $10 \%$ soil and $90 \%$ organic waste materials. Cow dung and agro-wastes in the ratio of $1: 1$ to $1: 3$ may be mixed and allowed to pre decompose for about 2 weeks in a separate tank adjacent to the Vermicompost tank, before being fed to the earthworms. Earthworms do not have mandibles and hence, only pre decomposed matter needs to be added. Agro wastes may cover farm waste like straws, feed residues, green leaves, grasses, toppings from trees, cattle shed wastes, kitchen wastes, animal dung of all animals except poultry birds, vegetable/flower wastes from markets, agro-industries waste like sugar factory press mud, etc. The ideal feed for earthworms could be leaf litters mixed with cow dung which helps to decompose the waste and increase the earthworm population.

Vermicomposting is a simple biotechnological process of composting in which certain species of earthworms are used to convert wastes into better end product. Vermicomposting is a non thermophilc biodegradation of organic material through the action of earthworms and microorganisms they modify its biological, physical, and chemical status, gradually reducing its $\mathrm{C}: \mathrm{N}$ ratio, increasing the surface area exposed to microorganisms, and making it much more favorable for microbial activity and further decomposition. It differs from composting in several ways. The vermicomposting process is faster than composting, because the material passes through the earthworm gut. The resulting earthworm castings (worm manure) are rich in microbial activity and plant growth regulators and fortified with pest repellence attributes as well Earthworms consume various organic wastes and reduce the volume by 40$60 \%$ Vermicompost contains a higher percentage of macro- and micronutrients than ordinary compost. It contains $9.8-13.4 \%$ organic carbon, $0.51-1.61 \%$ nitrogen, $\quad 0.19-1.02 \%$ phosphorus, and $0.15-0.73 \%$ potassium. The nutrients present in the Vermicompost are in water soluble forms which are immediately available for plant use.

Vermicomposting organic materials directly affect the growth and development of earthworms the crops produces the highest dry matter per unit area per unit time. At present, the vegetative parts of these crops are either ploughed back or burned. Byproducts of these root crops can be efficiently used for enriching the soil fertility. Earthworms are able to convert these byproducts (wastes) into nutrient rich Vermicompost. Keeping in view of the above, the present investigation was carried out to explore the possibilities of converting byproducts /wastes of different crop into quality Vermicompost. The study also attempted to ascertain the variability in nutrient content, microbial diversity, ve rmicomposting by different byproducts.The total decomposition may take about 75-100 days depending on various factors.

From Vermiculture, we get well decomposed vermi casts, which can be used as manure for crops, vegetables, flowers, gardens, etc. In the process, earthworms also get 
multiplied and the excess worms can be converted into vermiprotein which can be utilised as feed for poultry, fish, etc. Vermi-wash can also be used as spray on crops. Thus various economic uses can be obtained from organic wastes and garbage and prevent pollution. It has been estimated that organic resources available in the country alone can produce not less than 20 million tonnes of plant nutrients (NPK). The five major crops viz., paddy, jowar, wheat, bajra and maize alone are estimated to yield approximately 141.2 million tonnes of straw and legumes add another 10.0 million tonnes. It is estimated that annual domestic wastes of 25 million tonnes, 320 million tonnes of cattle manure and 3.3 million tonnes of poultry manure are generated annually in India. Vermicompost technology has promising potential to meet the organic manure requirement in both irrigated and rain fed areas. It has tremendous prospects in converting agrowastes and city garbage into valuable agricultural input. When organic manures are used, the chemical nutrients are also utilised well by crops as they improve soil health and balance the negative effects of chemicals.

\section{Material and Method}

\section{A culture}

experiment

on

vermicomposting of biomass and byproducts of different crop was conducted for March-May (season I) and June-August (season II) during 2014 at the college campus . The weather during March-May was hot and dry. The maximum temperature has reached $320^{\circ} \mathrm{C}$ during May. During June-August, the weather was wet and humid. The experiment was conducted in The treatments used in the experiment were garden fresh residues $(4 \mathrm{~kg})$, crop fresh leaves dry leaves $(1 \mathrm{~kg})$, The variation in quantity of substrate used was due to level of moisture content. Fresh leaves contain 80\% water, and dry leaves contain 16-20\% water. Four kg of fresh cow dung was added uniformly Small hole was made in the bottom of the pot to drain out excess water. The pots were kept on a plastic tray. In each plastic pot, the first layer from bottom $(3 \mathrm{~cm})$ was filled with small-size stones for good aeration and easy drainage of water. The second layer $(3 \mathrm{~cm})$ was filled with sand for proper filtration and to work as a check gate for preventing the earthworms to move to the bottom layer. The third layer $(3 \mathrm{~cm})$ was filled with garden soil, which is for maintaining the moisture level and to act as a bedding material for the earthworms. The fourth layer $(3 \mathrm{~cm})$ was filled with well-decomposed cow dung, and, above this layer, feeding materials (crop residue and fresh cow dung) were placed as per different treatments. The crop residue was chopped into small pieces before mixing with fresh cow dung. The feeding material was subjected to aerobic composting and was placed in the plastic pots after a week when the mixture was partially decomposed. Moisture content of the compost was maintained at 60$70 \%$. The earthworm Eudrilus eugenae obtained from the vermicomposting unit, in the plastic pots at 50 worms per pot. The experimental plastic pots were kept under shade and covered with wet jute bags to avoid direct sunlight. The Vermicompost was harvested when all the crop residues and byproducts and organic wastes were completely turned into castings. The Vermicompost and Vermicompost wash samples were collected in sterile containers before harvesting the compost, The weather during March-May 2014 was hot and dry, whereas during June-August wet and humid. The $\mathrm{pH}$, electrical conductivity (EC), organic carbon, nitroge $n$, phosphorus, and potassium content of the feeding materials.

General rate of application in different crops:

\begin{tabular}{|c|l|l|} 
Sr. No. & Diffe rent crops & Values \\
\hline 1. & Field crops: & $2-6 \mathrm{t} / \mathrm{ha}$ \\
\hline 2. & Vegetable crops: & $4-6 \mathrm{t} / \mathrm{ha}$ \\
\hline 3. & Fruit crops: & $2-6 \mathrm{t} / \mathrm{ha}$ \\
\hline 4. & Flower crops: & $2-6 \mathrm{t} / \mathrm{ha}$ \\
\hline 5. & Nursery bed and lawns: & $2-6 \mathrm{t} / \mathrm{ha}$ \\
\hline
\end{tabular}

Average nutrient content of vermi-compost and compost.

\begin{tabular}{|l|l|l|l|}
\hline Sr. No. & Nutrients & \multicolumn{1}{|c|}{$\begin{array}{c}\text { Vermi- } \\
\text { compost (\%) }\end{array}$} & $\begin{array}{c}\text { Compost } \\
(\mathbf{\%})\end{array}$ \\
\hline 1. & Nitrogen & $2.5-3.0$ & $0.7-0.96$ \\
\hline 2. & Phos phorus & $1.5-2.0$ & 1.8 \\
\hline 3. & Potassium & $1.5-2.0$ & 1.61 \\
\hline 4. & pH & $7-7.5$ & $6.8-7.5$ \\
\hline
\end{tabular}

\section{Results:-}

The Vermicompost from various feeding materials recorded more or less neutral $\mathrm{pH}$ ranging from 5.86 to 6.32 . The highest $\mathrm{pH}$ was found in garden residue Vermicompost during both the seasons. The lowest $\mathrm{pH}$ was observed in sweet potato dry leaves Vermicompost. In general, $\mathrm{pH}$ of the Vermicompost in season I was higher than in season II. The highest EC was noticed in Vermicompost in both the seasons. The lowest EC was observed in garden residue Vermicompost. In all the Vermicompost, higher EC was observed in season I than in season II. Vermicomposting decreased the organic carbon content (38.8-43.1\%) in all the different crops and byproducts. Garden residues Vermicompost 
had the lowest amount of organic carbon compared to all other Vermicompost.

All the Vermicompost recorded higher levels of nutrients than the original feeding materials. However, marked variation in nutrient content was noticed among the Vermicompost. The dry crop leaves Vermicompost had the highest nitrogen content in season I and II. It was followed by fresh crop leaves. The lowest nitrogen contents of $1.25 \%$ in season I and $1.12 \%$ in season II were recorded in feeding material. The Vermicompost obtained from dry crop leaves recorded the highest phosphorus content which was followed by the Vermicompost obtained from fresh crop leaves during the years, whereas, the lowest phosphorus content in the Vermicompost .The Vermicompost made from dry crop leaves recorded the highest potassium content. It was followed by fresh crop leaves. The lowest potassium content was recorded in feeding material du ring seasons of study.

\section{Discussion :-}

The total decomposition may take about 75-100 days depending on various factors. Therefore one tank may be used 4 to 5 times in a year for Vermicompost. A few days before the harvest watering of the tank is discontinued to allow migration of worms towards the bottom of the bed. The compost is the $n$ transferred outside without disturbing the bed and heaped on a plain open surface. The left over worms will then migrate to the center of the heap and can be collected and put back to the tank after segregation from the compost. The Vermicompost from various feeding materials had more or less neutral $\mathrm{pH}$, and it was less than the initial value. The lower $\mathrm{pH}$ recorded in the final products might have been due to the production of $\mathrm{CO}_{2}$, and microbial metabolism during decomposition of different substrates in the feed mixtures. However, the observed diffe re nce in reduction of $\mathrm{pH}$ among vermin beds could be attributed to the nature of organic waste, which affects the mineralization process and species of intermediate compounds in vermin reactors. Increase in electrical conductivity of the Vermicompost irrespective of kind of feed substrate was noticed. This may be attributed due to freely available ions and minerals that are generated during ingestion and excretion by the earthworms. The compost is sieved through a $3 \mathrm{~mm}$ mesh and then packed in gunnies. About $1700 \mathrm{~kg}$. of compost can be obtained from each cycle. While sieving the unhatched cocoons can also be retrieved.
The excess worms can be retrieved and put in new tanks or sold or can be sun-dried to make vermi protein. Per one cubic metre of composting volume, about $2 \mathrm{~kg}$. of worms (i.e. about 2000 nos.) need to be retained. The compost should be sun-dried and then bagged for sale/use. All the Vermicompost of different agro industrial wastes recorded higher levels of nutrients (nitrogen, phosphorus, and potassium) than the original feeding materials. Also demonstrated that nutrient content in the end product of vermicomposting was high. The increase of nitrogen content of the compost was probably due to mineralization of organic matter. Loss of organic carbon might be also responsible for nitrogen enhancement. Decrease in $\mathrm{pH}$ may be an important factor in nitrogen retention as this element is lost as volatile ammonia at higher $\mathrm{pH}$. Increase in nitrogen content in the final product in the form of mucus, nitrogenous excretory substances, growth stimulating hormones, and enzymes from earthworms has also been reported. Earthworms also have a great impact on nitrogen transformations in manure by enhancing nitrogen mineralization so that mineral nitrogen may be retained in the nitrate form. However, in general, final nitrogen content of the Vermicompost is dependent on the initial nitrogen present in the byproducts. Total phosphorus content in all the Vermicompost was higher than the initial feed substrate. Increase in phosphorus in Vermicompost is probably due to mineralization and mobilization of phosphorus as a result of bacterial and faecal phosphatase activity of earthworms. Potassium was also higher in the final Vermicompost than in the initial feed substrates. It indicated that the microbial flora also influences the level of available potassium.

The rate of increase in weight and population of the earthworms was found to be lowest in Vermicompost made from fresh crop leaves. The fully eliminated during partial decomposition and that might have influenced the growth and reproduction of earthworms. Furthermore, the earthworms might not have received sufficient microbes for feeding. Quality of substrate influences the fecundity of earthworms. In season II, the earthworm weight and population were higher than in season I. This was due to the influence of ambient temperature and relative humidity. Vermicomposting is a combined operation of earthworm and microorganisms. The nature of the feeding substrate and season influenced the populations of microorganisms Hot and dry 
conditions during March-May favored multiplication of bacteria and fungi in season I. Further, the growth and development of earthworms (which feeds microbes) was reduced during the above period. Wet and humid conditions between June and August might have been responsible for higher earthworm populations in season II. But there may be a microbial equilibrium existing among various kinds of organisms which decides the ultimate population. This might be due to the lesser number of earthworms which feed on microbes along with organic matter.

\section{Conclusion:-}

The crop waste, biomass and byproducts of different crops were vermicomposted in 40-65 days. They were fairly rich in major nutrients and bette $r$ in nutritional composition compared to initial levels. The nature of the feeding material determined the nutrient content, microbial diversity, earthworm population, and time required for complete vermicomposting. This study indicated that all biomass and byproducts of different crops can be effe ctively converted into high-value Vermicompost.

\section{Reference}

S. Bansal and K. K. Kapoor, "Vermicomposting of crop residue s and cattle dung with Eisenia foetida," Bioresource Technology, vol. 73, no. 2, pp. 95-98, 2000.

P. Garg, A. Gupta, and S. Satya, "Vermicomposting of different types of waste using Eisenia foetida: a comparative study," Bioresource Technology, vol. 97, no. 3, pp. 391-395, 2006.

S. Suthar, "Vermicomposting of vegetable-market solid waste using Eisenia fetida: impact of bulking material on earthworm growth and decomposition rate," Ecological Engineering, vol. 35, no. 5, pp. 914-920, 2009.

B. Sen and T. S. Chandra, "Chemolytic and solidstate spectroscopic evaluation of organic matter transformation during vermicomposting of sugar industry wastes," Bioresource Technology, vol. 98, no. 8, pp. 1680-1683, 2007.

K. P. Nagavallemma, S. P. Wani, S. Lacroix, et al., "Vermicomposting: recycling wastes into valuable organic fertilizer," in Global Theme on Agroecosystems, Report No. 8, p. 20, ICRISAT, Patancheru, Andhra Pradesh, India, 2004.

V. K. Garg, S. Chand, A. Chhillar, and A. Yadav, "Growth and reproduction of Eisenia foetida in various animal wastes during vermicomposting," Applied Ecology and Environmental Research, vol. 3, no. 2, pp. 51-59, 2005.

A. Yadav and V. K. Garg, "Recycling of organic wastes by employing Eisenia fetida," Bioresource Tech nology, vol. 102, no. 3, pp. 2874-2880, 2011.
M. Gandhi, V. Sangwan, K. K. Kapoor, and N. Dilbaghi, "Composting of household wastes with and without earthworms," Eco Environments, vol. 15, no. 2, pp. 272-279, 1997.

V. K. Garg and P. Kaushik, "Vermistabilization of textile mill sludge spiked with poultry droppings by an epigeic earthworm Eisenia foetida," Bioresource Technology, vol. 96, no. 9, pp. 1063-1071, 2005.

P. M. Ndegwa and S. A. Thompson, "Integrating composting and vermicomposting the treatment and bioconversion of biosoilds," Bioresource Technology, vol. 76, pp. 107-1 12, 2001.

B. Gunadi and C. A. Edwards, "The effects of multiple applications of different organic wastes on the growth, fecundity and survival of Eisenia fetida (Savigny) (Lumbricidae)," Pedobiologia, vol. 47, no. 4, pp. 321-329, 2003.

G. Tripathi and P. Bhardwaj, "Comparative studies on biomass production, life cycles and composting efficiency of Eisenia fetida (Savigny) and Lampito mauritii (Kinberg)," Biore source Technology, vol. 92, no. 3, pp. 275-283, 2004.

R. M. Atiyeh, J. Dominguez, S. Subler, and C. A. Edwards, "Changes in biochemical properties of cow manure during processing by earthworms (Eisenia andrei, Bouche) and the effects on seedling growth," Pedobiologia, vol. 44, no. 6, pp. 709-724, 2000 .

P. M. Ndegwa, S. A. Thompson, and K. C. Das, "Effects of stocking density and feeding rate on vermicomposting of biosolids," Bioresource Technology, vol. 71, no. 1, pp. 5-12, 2000.

J. Dominguez, "State of the art and new perspectives on vermicomposting research," in Earthworm Ecology, C. A. Edwards, Ed., pp. 101424, CRC Press, 2nd edition, 2004. 